\title{
The Productive Powers of Labour and the Redundant Transformation to Prices of Production
}

\section{A Marx-immanent Critique and Reconstruction}

\author{
Geert Reuten
}

School of Economics, University of Amsterdam

reuten@uva.nl; http://reuten.eu

\begin{abstract}
The famous Marxian 'transformation problem' originated from a research manuscript written by Marx in 1864/65, from which Engels assembled Capital III (1894). Unequal capital compositions, equal rates of surplus-value and equal rates of profit among different sectors are posited, and reconciled using the problematic concept of 'prices of production'. Yet the assumption of equal rates of surplus-value is at odds with the subsequent text of Capital I (1867), where Marx presents various determinants of the rate of surplus-value, and connects productive powers of labour diverging between sectors with divergent value-generating potencies of labour. Given the other determinants, diverging rates of surplus-value then result. Marx disregarded these productive power differentials when he originally formulated his transformation. In a reconstruction, building on Capital I, this omission is rectified. It makes prices of production and hence the dual account systems redundant. The transformation problem then evaporates.

* This article is a revised and briefer version of a chapter that appears in Marx's Capital - An Unfinished and Unfinishable Project?, edited by Gerald Hubmann and Marcel van der Linden (Historical Materialism Book Series). The first version was presented at a conference, under the same title, organised by the Berlin-Brandenburgische Akademie der Wissenschaften and the International Institute of Social History, Amsterdam, on 9-11 October 2014. I thank the participants for their discussion of that paper. In rewriting the text for that chapter (the second version), I benefitted especially from the comments by Chris Arthur, the main commentator at the conference. I also benefitted from a written comment by Fred Moseley, from oral and written comments by Boe Thio, and from Jurriaan Bendien's correspondence and copyedits (all these scholars participated in the conference). The current third version has greatly benefitted from comments by the Historical Materialism editors and by three anonymous reviewers, for which I am grateful.
\end{abstract}




\section{Keywords}

Marxian transformation problem redundant - Marx's prices of production redundancy - Marxian transformation problem reconstructed - Marx's productive powers of labour - Marx's intensity and potency of labour - Marx's rate of surplusvalue divergences

\section{Introduction}

In this article I revisit what probably is the main theoretical problem in Capital, namely the transformation of the Capital I value concepts into the 'prices of production' of Capital III, Part Two. Marx's own approach to this transformation, and its implications, was subsequently dubbed the 'transformation problem'.

Marx sets out this transformation in an $1864 / 65$ research manuscript of 'Capital III'. At this time Capital $I$ existed in a draft form that differed from the version that was actually published in 1867 . In the $1864 / 65$ manuscript some key 'Capital I' concepts - referring to averages of the capitalist economy at large - are transformed into concepts referring to the particular sectors (or branches) of production. Here he posits a configuration of so-called 'prices of production', defined by ratios of capital and wages (capital compositions) which diverge in each sector, equalised rates of surplus-value, and equalised profit rates. After Marx's death in 1883, Engels edited and published this research manuscript in Part Two of Capital III (1894). Soon after, however, it was discovered that Marx's transformation contains a serious flaw (see section 2 below). This flaw, and later formal-analytical extensions of it, came to be known as 'the Marxian transformation problem'. I agree with many of the formal-analytical criticisms, and it is not my intention to repeat them here. ${ }^{1}$ Note though that the scholarly transformation controversy mainly concerns issues that Marx himself never dealt with. In that sense these are external criticisms, although this does not disqualify them.

My own aim in this article is to set out an immanent critique of the way in which Marx posited the transformation in $1864 / 65$. For this immanent critique, I rely on the $1866 / 67$ thoroughly-reworked version of Capital I. In a reconstruction I transcend the transformation as a concretisation of the Capital I concepts of value and surplus-value. This concretisation makes the (current Capital III ) concept of prices of production redundant, as a result of which the transformation problem evaporates. Instead of dual accounts for values and

1 For an overview, see Schefold 2004. 
prices of production, my reconstruction posits one single account. ${ }^{2}$ My argument focuses on the frail constraints of the transformation procedure posited by Marx himself, and thus interprets the problem to be wider in scope than in the usual appraisals.

In Capital I, Part Four, Marx presents the determinants of relative surplusvalue and the concomitant rate of surplus-value, a major one being the 'productive powers' of labour (also translated as 'productive forces'). He associates sectoral divergences in the productive powers with divergent value-generating potencies of labour. Given the other determinants of the rate of surplus-value, we then obtain diverging rates of surplus-value. In the $1864 / 65$ research manuscript of 'Capital III', however, Marx posits equalised rates of surplus-value, either because he had not yet developed the Capital I notion just referred to, or because he disregarded this productive-powers determinant for unknown reasons.

My reconstruction shows how, predicated on this productive-powers determinant, diverging rates of surplus-value are associated with diverging compositions of capital and equalising rates of profit, maintaining throughout the monetary-value dimensions of Capital I. Since in the reconstruction 'prices of production' are redundant, that monetary-value dimension also captures balanced and non-balanced prices generally.

In line with Marx's own view in the $1864 / 65$ manuscript, the received view on the transformation is that the texts for Capital III put the argument of Capital $I$ into question. Inverting that interpretation, I will show that the later finalised Capital I theory instead puts the drafts for the Capital III transformation into question.

After some methodological and value-theoretical remarks $(\S 1)$ followed by a summary of the transformation problematic (§2), I will focus on the concept of relative surplus-value in Capital I's Part Four $(\S 3)$. With that background, I then provide the main elements for a Marx-immanent reconstruction which transcends the transformation $\left(\S_{4}\right)$.

The admittedly difficult and controversial idea I propose is that Marx himself posited the problematic in such a way that a transformation problem could emerge which remains irresolvable because of its deficient premises. Thus, more than a hundred and twenty years after 1894, I want to argue that the problematic may well have been wrongly posited by Marx himself in his drafts, and

2 On very different grounds, and without considering prices of production as a redundant concept, a single-system account is also proposed by the Tssi school ('temporal single-system interpretation') - I might mention Carchedi, Ernst, Freeman, Kliman, Maldonado-Filho, McGlone, Potts, and Ramos Martinez - as well as by Moseley (e.g. Moseley 2015). See the latter's Chapter 9 for references on the TSSI school. 


\begin{tabular}{llll}
\hline Volume & Dating & Draft & Remarks \\
\hline C I & $1863-64$ & penultimate draft & $\begin{array}{l}\text { lost or blended into final } \\
\text { draft (see §2) }\end{array}$ \\
C III & $1864-65$ & first full research ms. & \\
C II & 1865 & first research ms. & \\
& early 1866 & & $\begin{array}{l}\text { Engels convinces Marx that } \\
\text { he should bring out C-I, even } \\
\text { when C-II and C-III are not } \\
\text { completed }\end{array}$ \\
& & & \\
C I & $1866-67$ & final draft first edition & \\
\hline
\end{tabular}

SOURCE: VOLLGRAF $2012 .^{3}$

therefore by his latter-day critics as well. In that case, the difficult challenge for us is to transcend the way the issue was originally framed.

Because the dating of Marx's manuscripts for Capital is important to this article, I present these in tabular form.

Making the argument in this article necessarily involves quite a number of terminological references, as well as citations from German and English texts, for which I adopt some conventions. I render the German noun 'Darstellung' as 'exposition', and use 'exhibit' to refer to the setting-out of this exposition. With regard to Marx's research manuscripts, the German noun 'Forschung' is rendered as 'investigation' and I use 'write', 'set out' or variants thereof for the setting-out of this investigation. Within cited passages, the italics are always an emphasis in the original. Underlining indicates my own emphasis. Unproblematic insertions in quotations are rendered in square brackets. My own comments are in braces. The abbreviation 'mt' after a page number (e.g. 370-mt) denotes my own translation. Within my translations, an original German term is likewise

3 Between 1868 and his death in 1883, Marx's continuation of Capital is very briefly as follows (for details, see Vollgraf 2018):

On Capital I: second edition (of 1872); third edition (of 1883); French edition (of 1872-5).

On Capital II: $1868-70$ and 1877-81.

On Capital II : conceptual, mathematical and comparative statistical studies (no new drafts). 
inserted within braces. References to the published texts of Capital are rendered in italics. When I refer to manuscripts prior to it, these are non-italicised in quotation marks ('Capital I', 'Capital III').

To place the argument in its appropriate theoretical context, I will first make five relevant points about Marx's method and the value-theoretical dimensions which he uses.

1. In Capital, Marx's methodology of exposition involves different stages. He moves from the production of capital (Book I), to capital's circulation which includes the realisation-conditions of production (Book II), and finally to the concretisation of the former two stages, distinguishing on the one hand capital in its particular material manifestation (Gestaltungen) of sectors of production, and on the other its functional forms, such as industrial capital and finance capital (Book III). Although in my view there are good reasons for interpreting Marx's method as a systematic-dialectical one, the argument of the current paper does not rely on that interpretation. ${ }^{4}$ I want to emphasise here only that - contrary to most 'economic modelling' approaches - Marx's method is one in which the general statements established within each one of these three stages must be claims to general truth. In particular, if for example a level III statement would turn out to be inconsistent with a level I statement, one of those statements must be false. (As regards a core theme in my argument in this article, for example, we cannot combine the first-stage general statement that the production of commodities and commodity transactions is determined by their value - as explained by labour-time - and a next-stage general statement that, instead, commodity production and transactions are determined by prices of production that are only partly determined in that way. Similarly, we cannot combine the initial general statement that capitalist production is motivated by the production of surplus-value only, with another general statement that it is determined by an amalgamation of surplus-value and a capital-size related profit-levelling (dis)agio.) In brief: the abstract statements must be true statements; they must, without additional qualification, cover the richer and more-concrete statements.

2. In Marx's way of exposition of the production process in Capital I - the production of surplus-value and therefore of capital - he is able to abstract

4 For various accounts of the systematic-dialectics, see the contributions in Moseley and Smith (eds.) 2014. 
from ('bracket') all kinds of factors that do not affect this core matter (including the realisation restrictions in Capital II, and the financiers' share in surplus-value in Capital III). In this way he can show how labour is the overall determinant for the production of surplus-value and capital.

3. The first chapter of Capital $I$ is complex. ${ }^{5}$ In my view, it ought to be read in the context of the Ricardian labour-embodied theory of value which predominated in those days (recall the subtitle of Capital I).${ }^{6} \mathrm{~A}$ main result of the chapter is that he breaks away from Ricardianism. For example, implicitly opposing Ricardo, Marx writes: 'Human labour-power in its fluid state, or human labour, creates value, but is not itself value. It becomes value in its coagulated state, in objective form \{i.e. commodities\}. ${ }^{7}$ Thus the value of commodities is explained by labour-time. However, a full comprehension of this chapter requires a reading interconnected within the full Part One (i.e. Chapters 1-3), as including especially Chapter 3 on money.

4. It follows from this Part One that in Capital I, as for all of Capital, value entities are expressed within a monetary dimension (using some currency standard such as $£$ ); the same applies to all numerical examples. ${ }^{8}$ It is important to emphasise this since in some interpretations of Marx's theory, 'value' is itself taken to have a labour-time dimension (those same accounts often adopt the term 'labour values' - one that is never used in Capital). ${ }^{9}$ At the expositional level of the production of capital (Capital I) Marx aims to explain value and surplus-value (within a monetary dimension) in terms of labour-time (in Parts Three to Five, $35^{\circ}$ pages) - an explanation in terms of labour-time does, of course, not mean that value ever discards its monetary dimension. ${ }^{10}$

5 Marx himself admits that the chapter is complicated - see his Foreword to the first edition (1867).

6 A distinction ought to be made between, first, the dominance of a school of thought (here, the Ricardian one) in university-teaching and in common appraisal and, second, research leading to new thought that might perhaps become a new dominant school in teaching and appraisal later on. There are considerable time-lapses between the two.

$7 \quad$ Marx $1976\left[1890^{4}\right]$, p. 142.

8 This was pointed out by Elson (1979).

9 For example, Schefold (who is generally well acquainted with the field) does presume this. Thus, in his introduction to Capital III, Schefold erroneously writes 'Arbeitswerten (wie Marx sie nannte) [Labour-values (as Marx called them)]' (Schefold 2004, p. 874). Possibly Marx used this expression in some writing prior to Capital - Schefold cites no source - but that would surprise me very much.

10 In section 1.1 of Reuten 2004, I trace the dimensions and measures adopted by Marx in the explanatory Parts Three to Five of Capital I. 
5. Even if Marx breaks with Ricardo (point 3 above), for some, including myself, this break is not complete. ${ }^{11}$ Whereas I am a proponent of a value-form theoretical interpretation and reconstruction of Capital $I$, Part One, that is not relevant for my argument in this paper. ${ }^{12}$ This paper is not about Capital I, Part One as such, and it mainly builds on its Parts Three to Five, in which such disputed matters are absent or not prominent. What is more, the reconstruction that I propose in $\S 4$ should fit any interpretation of the value-theoretical categories. For each interpretation, the reconstruction does away with dichotomous 'value'-'prices of production' algorithms, and results in a continuity of the concept of value for each of Capital's levels of exposition. This conceptual continuity includes all specific and concrete market phenomena in terms of balanced or imbalanced market prices (Capital II, Part Three and Capital III, Part One). However, it excludes 'prices of production' and hence dual-account systems.

In this article I shall refer to the field of Capital III, Part Two, as 'the general rate of profit transformation' (abbreviated as 'GRP transformation'). In the research manuscript for it, of $1864 / 65$, Marx sets out a concretisation of his 'Capital I' categories, in face of the tendency toward equalisation of rates of profit between sectors, or to the formation of a 'general rate of profit' (GRP). ${ }^{13}$ In face of the 'Capital I' concepts of value and surplus-value, Marx refers to this concretisation as a 'transformation'.

I assume that many readers have at least a general acquaintance with Marx's GRP transformation (that is, of Engels's rendering of it in his edition of Capital III) and with its problems: 'the transformation problem(s)'. In brief, Marx posits the relationships between sectors of production as: (1) equal or equalising rates of profit; (2) diverging compositions of capital; and (3) equal

11 See the references in Reuten 1988 and 1993; here I merely mention the pivotal paper by Backhaus 1969 (English translation 1980). However, the value-form theoretic critique does not dispute Marx's explanation of surplus-value in terms of labour-time (that is, at least, my own take on value-form theory). Regarding Part One's Chapter 3, a main problem is that Marx's theory of 'commodity money' is clearly a nineteenth-century theory that is not applicable in the current age (see Campbell 1997, Williams 2000 and Bellofiore 2005 - these are contrary positions, though in my view in the end complementary ones).

12 I should add here that in the opinion of one anonymous reviewer it is relevant.

13 The research manuscript is published in MEGA II/4.2 (1993). Engels's editorial work is published in MEGA II/14 (2003). MEGA II/15 (2004) contains the critical edition of Das Kapital III of 1894 . 
or equalising rates of surplus-value. He then feels (reluctantly) constrained to drop his 'Capital I' commodity sales at value, and to introduce 'production prices' instead. ${ }^{14}$

The standard critique of Marx's GRP transformation procedure is that it is a 'halfway house'. He transforms Capital I output quantities into Capital III output quantities, neglecting to apply that transformation to the inputs. ${ }^{15} \mathrm{He}$ therefore obtains incorrect results (especially regarding the simultaneous aggregate equalities of, on the one hand, the commodity values and the prices of production of commodities, and on the other, surplus-value and profit). This critique is accurate (though see footnote 2), and it has been extensively dealt with already in the literature. ${ }^{16}$

However, in a way this was not Marx's problem, since he (mistakenly) neglected it, or was not aware of it.17,18 Elsewhere, I approach the matter rather from the perspective of the problems that Marx was aware of in the 1864/ 65 manuscript. ${ }^{19}$ There it is set out how Marx is sceptical and worries about his transformation, the main point being that his transformation cannot simply be combined with his text for 'Capital I' - i.e. its draft at the time (1864/65). Howard and King comment: 'Engels accepted Marx's defective solution to the transformation problem uncritically. He did not, indeed, follow up or even comment upon the uncertainties expressed by Marx himself concerning the volume III solution. ${ }^{20}$ In my view Marx's own worries overarch those of the post-Marx criticisms: even if he would not have made the formal mistake of neglecting the transformation of inputs, his own problems with the manuscript

14 Reuten 2018 forthcoming, section 2, provides an overview and a critical discussion of that text. Reuten 2009 discusses the transformation issue mainly in methodological terms.

15 Here I refer to the published versions (Capital I, Capital III) as they appeared for the reader at the time of publication of the third Volume. In his Foreword to the latter, Engels provides the reader no hint concerning the order in which Marx wrote the published manuscripts - see Table 1 above (even though some readers might perhaps have inferred this from Engels's Foreword to Capital $I I)$.

16 See the overview by Schefold (2004, pp. 875-95).

17 Perhaps he was aware of it in other contexts (see e.g. his 1861/63 discussion of Bailey in the Theories of Surplus-value, MECW 32, pp. 352-3; I thank Jurriaan Bendien for pointing this out). Marx seems nearly aware of it in his manuscript for Capital III, 'Chapter 12' (M:283; cf. E:217, EF:309) - see the next footnote for these shorthand references.

18 In this section I use the following shorthand references: M = Marx 1993 (Marx's 1864/65 research manuscript for Das Kapital III, MEGA II/4.2); MF = Marx 2015 (Fowkes's translation of the former); E = Marx 1964 (Engels's 1894 edition of Das Kapital III, Marx-EngelsWerke Band 25); EF = Marx 1981 (Fernbach's translation of the former: Capital III).

19 In Reuten 2018 (section 2).

$20 \quad$ Howard and King 1989, p. 37. 
would still prevail. These problems are not resolved in the standard post-Marx solutions to the transformation problem.

In the remainder of the current section I merely focus on one passage, from what became Chapter 10 of Capital III, where Marx writes that equality in the rate of surplus-value is not just a simplifying theoretical presupposition, but rather a law which is predicated on competition between workers:

[E]quality in the grade of exploitation of labour or the rate of surplusvalue (...) presupposes competition among the workers and an equalisation that takes place by their continual migration from one sphere of production to another.

MF:286-AMENDED; M:250; CF. E:184, EF:275 21

Anticipating $\S 3$ and $\S 4$, I indicate already here that I have no problems with this competition determinant of the rate of surplus-value (concerning the 'intensity of labour'). In this manuscript, however, Marx neglects the productive-powers determinant of the rate of surplus-value that we find in Part Four of Capital I, which has nothing to do with competition between workers (see §3.2). However, we do not know what manuscript of 'Capital I' Marx had before him in $1864 / 65$. The draft of $1863 / 64$ for Capital $I$ is either lost (as much was suggested previously by the MEGA II $/ 5$ editors), ${ }^{22}$ or - and this is the recent expert opinion - it was blended (verschnitten) into the final version compiled for the printer (as convincingly argued by MEGA II editor Vollgraf). ${ }^{23}$

\section{3 'Productive Powers', 'Intensity of Labour' and the Rate of Surplus- Value in Capital $I$}

\subsection{Preliminary Remarks}

Six preliminary remarks are in order here:

1. In the next section (§4), I present an immanent reconstruction of the GRP problematic - 'immanent' in the sense that I base myself on Marx's own text. Divergent rates of surplus-value in different sectors of production are at the

21 Marx continues: 'A general rate of surplus-value of this kind - as a tendency, like all economic laws - is presupposed by us as theoretical simplification; but in practice it is an actual presupposition of the capitalist mode of production, even if inhibited to a greater or lesser extent by practical frictions.... In theory we presuppose that the laws of the capitalist mode of production develop in their pure form.' (Translation amended.)

22 See Kopf, Bang, Conrad and Klapperstück 1983, pp. $15^{*}-16^{*}$.

23 Vollgraf 2012, p. 465; his full argument can be found on pp. 464-7. 
core of this reconstruction. In $\S 3$, I therefore reconsider Marx's exposition of surplus-value and the rate of surplus-value in Capital $I$, in order to argue that the key to the solution of the transformation problematic is found in Capital I, Parts Four and Five, on the production of relative surplus-value.

2. Recall Marx's exposition of surplus-value in Capital $I$, in which he draws a distinction between absolute surplus-value (Part Three) and relative surplusvalue (Part Four), each predicated on some given real wage per working day. Then the absolute surplus-value varies with the length of the working day. The relative surplus-value varies with the production costs of the wage bundle. Thus, at a given length of the working day (and hence with a given absolute surplus-value), the surplus-value in its aspect of relative surplus-value may increase, when the value of commodities that make up the wage bundle decreases (and vice versa).

3. Recall from my §1 that 'value' has a monetary dimension, and that Marx aims to explain value and surplus-value in terms of labour-time.

4. It is relevant to emphasise that, in most of Capital I, Marx reasons from economic averages - including their change. ${ }^{24}$ This applies especially also for most of what Marx develops in the $35^{\circ}$ pages of Parts Three to Five, where he discusses (changes in) the 'average' production of surplus-value and the average capital. Marx repeats over and again that he is only considering averages (also alternated with the term 'normal'). Except when he discusses changes (especially in productive powers), differences between sectors are bracketed out.

5. It is just as relevant that the concept of the 'composition of capital' (the $\mathrm{c} / \mathrm{v}$ ratio) makes its proper appearance only in Part Seven of Capital I. In the relevant Parts Four and Five, the capital composition is mostly only implicit (it is alluded to in Part Four's Chapter $\left.15^{\mathrm{Ger} .13}\right) .{ }^{25}$ Notably it is not alluded to in Chapter $12^{\mathrm{Ger} .10}$ on the productive powers of labour, where the discussion in the next subsection starts.

6. From the 1845/46 German Ideology onwards, Marx adopts the term Produktivkräfte (in $M E C W 5$ it is translated as 'productive forces'). Regarding the standard English translation of Capital I by Ben Fowkes, I note here that he

24 I stressed this in Reuten 2004, but it is emphasised much more by Vollgraf (2012, pp. 450-1). He points to Marx's acquaintance with the work of Quételet, a Belgian mathematician and statistician who in a work of 1835 was the first to apply 'averages' in social science. Vollgraf also quotes Marx on Quételet from the $1863-5$ manuscript (p. 879). In a footnote in Capital I, Marx refers in passing to Quételet (Marx 1867, p. 261, n. 8; Marx 1962, p. 342, n. 8; Marx 1976, p. 440, n. 1).

Marx $1962\left[1890^{4}\right.$ ], pp. $466-7$ and 473-4; Marx 1976 [transl. $1890^{4}$ ], pp. 571 and $577^{-8}$. 
translates the German Produktivkraft der Arbeit as 'productivity of labour'.6 This does not cover the meaning of the term. It is moreover unfortunate, because Marx sometimes also uses the term Arbeitsproduktivität (labour productivity). In all of the following citations, I have amended the translation for Produktivkraft to 'productive power' (marked *...*); I use the same mark for any other amendments of the translation). Fowkes also misses the related term potenzierte Arbeit (see below). The same applies for the Moore and Aveling translation. These remarks highlight that the art of translation is inevitably also one of interpretation. All English citations below have been checked against the German.

References in this section are as follows: $\mathrm{M}^{1}=$ Marx $1867^{1}$ (Das Kapital $I$, first edition 1867, MEGA II.5); $\mathrm{M}^{4}=$ Marx 1962 (Das Kapital I, fourth edition 1890, Marx-Engels-Werke Band 23); MF = Marx 1976 (Capital I, fourth edition 1890 in the Fowkes translation). All key quotations in this section have also been checked against the first German edition of Capital (1867), because that is nearest to the $1864 / 65$ manuscript. Chapter references are to the English editions, with those of the German editions as superscript (e.g. Chapter $15^{\text {Ger.13 }}$ ).

\subsection{The Productive Powers of Labour: Degree of Value-generating Potencies of Labour}

I will now show how Marx posits diverging rates of surplus-value between sectors of production according to the development of the productive powers. Marx systematically introduces the 'productive power' of labour in Part Four, Chapter $12^{\text {Ger.10. } 27}$

26 Most of the time at least - e.g. on page F:453, second paragraph, Fowkes translates Produktivkraft as 'productive power', and on page F:508 it is translated as 'productive forces' (cf. $\mathrm{M}^{4}: 407$ ). Not only do we lose terminological connections, the English text also makes connections that are absent from the German (especially with the German term Produktivität der Arbeit, and when Fowkes translates this as 'productivity of labour', 'productivity' being his most frequent translation for 'Produktivkraft'). We have the same problem in the Results (translated by Livingstone). Moore and Aveling (Capital I, edition of 1887) translate Produktivkraft as 'productiveness' (at least in those instances that I have checked). Generally there are two translation options for the term Kraft as in Produktivkraft: power and force. The former is adopted in the Grundrisse translation (productive power) and the latter in The German Ideology and the 1859 Critique Introduction (productive force). I do not mind which single translation is adopted, provided that the translation is consistent. In what follows I use 'productive power'. At the

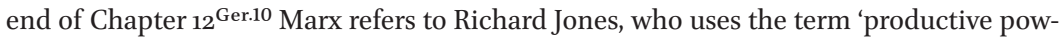
ers'. Marx in his German text translates this as 'Produktivkräfte', which is one reason for me to incline toward the 'productive powers' translation.

27 Earlier (Chapter 1) he wrote: “*The productive power of labour* is determined by a wide range of circumstances; it is determined amongst other things by the workers' average degree of skill, the level of development of science and its *technological applicability*, 
[I]ncrease in the *productive power* of labour (...) cannot be done except by an alteration in his [the labourer's] tools or in his mode of working, or both. Hence the conditions of production of his labour, i.e. his mode of production, and the labour process itself, must be revolutionized. By an increase in the *productive power* of labour, we mean an alteration in the labour process of such a kind as to shorten the labour-time socially necessary for the production of a commodity, *hence a smaller quantity of labour acquires the force* of producing a greater quantity of use-value.

MF:431 AMENDED; $\mathrm{M}^{4}: 333$

In other words, the effect of such a change is that one worker works up more means of production. Marx considers the transition from the one state of the productive powers to a new one as initiated by some individual capitalist. ${ }^{28} \mathrm{As}$ regards the labour producing at the increased productive power, he states the following key sentence:

The labour operating at this exceptional productive power acts as potentiated labour; it creates in equal periods of time greater values than average social labour of the same kind.

MY TRANSLATION; CF. MF: $435^{29,30}$

Die Arbeit von ausnahmsweiser Produktivkraft wirkt als potenzierte Arbeit oder schafft in gleichen Zeiträumen höhere Werte als die gesellschaftliche Durchschnittsarbeit derselben Art.

$$
\mathrm{M}^{4}: 337 ; \mathrm{M}^{1}: 257^{31}
$$

the social organisation of the process of production, the extent and effectiveness of the means of production, and the conditions found in the natural environment.' (MF:130 amended; $\mathrm{M}^{4}: 54$.).

28 MF:433-6; $\mathrm{M}^{4}: 335^{-8}$.

29 Fowkes (Marx 1976, p. 435) renders this as: 'The exceptionally productive labour acts as intensified labour; it creates in equal periods of time greater values than average social labour of the same kind.' We find the 'intensified' also in the earlier translation by Moore and Aveling (Marx 2010 [1887], p.323). This is wrong, also because it risks making a confusing reference to the treatment of 'intensity of labour' discussed in Chapter $15^{\text {Ger.13. Marx, }}$ as we will see, carefully distinguishes the two.

30 Instead of 'potentiated labour', an alternative translation for 'potenzierte Arbeit' might perhaps be 'exponentiated labour'.

31 In the first edition, there are two emphases: 'Die Arbeit von ausnahmsweiser Produktivkraft wirkt als potenzirte Arbeit oder schafft in gleichen Zeiträumen höhere Werthe als die gesellschaftliche Durchschnittsarbeit derselben Art.' ( $\left.\mathrm{M}^{1}: 257.\right)$. 
Therefore, the above-average potentiated labour - labour with extra valuegenerating potencies - cannot be simply measured in clock-time. Note that Marx thus draws a distinction between the 'value productivity of labour' (the value produced per unit of time) - the last quotation - as opposed to labour's 'use-value productivity' (the physical quantity of commodities produced per unit of time) - the last-but-one quotation. Marx continues:

Hence, the capitalist who applies the improved method of production, *appropriates as surplus-labour* a greater portion of the working-day than the other capitalists in the same business. He does as an individual what capital itself taken as a whole does when engaged in producing relative surplus-value. On the other hand, however, this extra surplus-value vanishes, as soon as the new method of production is generalized ...

$\mathrm{MF}: 436 ; \mathrm{M}^{4}: 337$

Thus Marx feels (rightfully) constrained to exhibit a change in the sociallyaverage production power as a change within one sector of production (of course other changes may occur in other sectors). Note that whereas he suggests a generalisation of the implementation of productive powers within a sector, he (rightfully) posits no mechanism for inter-sectoral generalisations of the development of the productive powers (equalisation of compositions of capital?!). However, given the value-generating potencies, this implies divergences in rates of surplus-value between sectors - that is, under the condition that there are diverging productive powers of labour. Thus whereas there seems to be no direct measure for the comparison of the physical use-value productivity of labour between sectors of production (indirectly there is one - see the next sub-section), there is a measure for the value productivity of labour between sectors, which is the value-added per unit of labour time. Given the real-wage rate per unit of labour time, this value productivity can be measured by the rate of surplus-value.

Note that in the last quotation, Marx posits the 'exceptional' and 'vanishing' character of the implied divergences in rates of surplus-value (apparently due to competition). However, this circumstance is not obvious. The point is that, in the current exposition, Marx is not explicit about the composition of capital. Should a change in productive powers in a sector go along with an abovetotal-economy-average $\mathrm{c} / \mathrm{v}$, then the extra surplus-value or some of it will not vanish, whence we have persistent sectoral diverging potencies of labour and concomitantly diverging rates of surplus-value. (See $\S 4-$ and in more detail the Appendix, section A§2.) 
The concept of 'potentiated labour' reoccurs one more, relevant, time in Capital I (Chapter $15^{\text {Ger.13) }}:{ }^{32}$

Machinery produces relative surplus-value, not only by ... cheapening the commodities that enter into its [labour-power's] reproduction, but also, when it is first introduced sporadically into an industry, by converting $\{$ verwandlen $\}$ the labour employed by the owner of that machinery, into *potentiated" labour ... During this transitional period, while the use of machinery remains a sort of monopoly, profits are exceptional $\{$ außerordentlich\} ...

MF:530 AMENDED; $\mathrm{M}^{4}: 428-9 ; \mathrm{M}^{1}: 333^{33}$

In the same chapter $\left(15^{\text {Ger.13 }}\right)$, we find another reference to divergent sectoral rates of surplus-value related to the productive powers: ${ }^{34}$

The use of machinery for the exclusive purpose of cheapening the product is limited (...) by the difference between the value of the machine and the value of the labour-power replaced by it. Since the division of the day's work into necessary and surplus-labour differs ... ${ }^{*}$ simultaneously* in different branches of industry .... it is possible for the difference between the price of the machinery and the price of the labour-power replaced by that machinery to *vary very much* (...) [It] determines the cost to the capitalist of producing a commodity, and influences his actions through the pressure $\{$ Zwangsgesetze $\}$ of competition.

MF:515-16 AMENDED; $\mathrm{M}^{4}: 414 ; \mathrm{M}^{1}: 321^{35 \mid 36}$

Comment. Overall, we find in Capital I three types of statements and arguments about generalisations and averages:

32 In $\$ 3.5$ I will refer to another, different, occurrence.

33 The latter (Marx $1867^{1}$ ) has several terms emphasised, including 'potentiated' (potenzirte) and 'transitional'.

34 I thank Boe Thio for drawing my attention to this passage.

35 The latter text (Marx 1867 $)$ has several phrases emphasised.

36 The text that I emphasised reads in German (in full): 'Da die Teilung des Arbeitstags in notwendige Arbeit und Mehrarbeit in verschiednen Ländern verschieden ist, ebenso in demselben Lande zu verschiednen Perioden oder während derselben Periode in verschiednen Geschäftszweigen;...' 
- First, generalisations (which are applicable in each case). For example, in capitalism, production takes the form of commodity production; or, value takes the form of monetary value.

- Second, averages accounts. In Capital I, these are most often social averages (for the economy at large). A problem with Marx's terminology is that he often conflates 'general' and 'grand average' throughout his research manuscripts and final texts - sometimes explicitly. ${ }^{37 \mid 38}$

- Third, distinctions within the averages. In Capital I, Marx mostly summarises these later on in the text, in terms of averages (for the distinctions above, we will see this in §3.4).

Each time, the reader has to be very alert about the type of statement Marx is actually making. Thus, in the quotations that I provided above, Marx sets out sectoral distinctions and, in particular, differences in rates of surplus-value. These are of course levelled out in an averages account. One of my main points is that when we get to sectors of production in a systematic way (the concretisation of Capital III, Part Two), all these sectoral distinctions - including diverging rates of surplus-value - must regain account.

\subsection{Intensity of Labour: Degree of Value-generating Density of Labour}

In Chapter $15^{\text {Ger.13 }}$ of Part Four, Marx systematically introduces the 'intensity of labour'. One important point about it is that, once again, labour-time cannot be simply measured in terms of clock-time. Now, however, for reasons other than those for changes in productive powers. He writes:

It [intensification of labour] imposes on the worker an increased expenditure of labour within a time which remains constant, a heightened tension of labour-power, and a closer filling-up of the pores of the working day, i.e. a condensation of labour, to a degree which can only be attained within the limits of the shortened working day. This compression of a greater mass of labour into a given period now counts for what it really is, namely an increase of the quantity of labour. In addition to the measure of its 'extensive magnitude', labour-time now acquires a measure of its

\footnotetext{
37 As in the title of Capital III, Chapter 9, which is identical in the research manuscript: 'Formation of a general rate of profit (average rate of profit), and ...'

38 One reason might be that Marx is only gradually making up his mind about the importance of averages - see Vollgraf 2012, referred to in the first footnote of §3.1.
} 
*degree of density*. ${ }^{39}$ (...) The same mass of value is now produced for the capitalist by, say, $3^{1 / 3}$ hours of surplus labour and $6 \frac{2}{3}$ hours of necessary labour, as was previously produced by 4 hours of surplus labour and 8 hours of necessary labour.

MF:534 AMENDED; $M^{4}: 432-3$

Marx next uses terms like 'degree of power exerted [Grad der Kraftäußerung]', 'energy of labour' and 'discipline' (MF:535; $\mathrm{M}^{4}: 433$ ). In brief, it concerns the effort and strain of labour. In so far as there are intra-sector or inter-sector differences in intensity, and to the extent that it is the intensity that affects divergences in the intra-sector or inter-sector rates of surplus-value, these are likely to be levelled out by intra-labour competition. From this perspective, and this one only, the Marx of $1864 / 65$ is quite right to posit equalised rates of surplusvalue (see the quotation in $§ 2$ ).

\subsection{Separate and Combined Average Variations in Productive Power and Intensity}

In Chapter $17^{\text {Ger.15 }}$ of Part Five - synthesising Parts Three and Four - the main focus is on social averages (this also applies for the next and last chapter of this Part, which I will not discuss here). Marx indicates that at a given average real-wage rate per 'normal working day', the rate of surplus-value depends on:40

(1) the length of the working day, or the extensive magnitude of labour, (2) the normal intensity of labour, or its intensive magnitude, whereby a given quantity of labour is expended in a given time and (3) the *productive power* of labour, whereby the same quantity of labour yields, in a given time, a greater or a smaller quantity of the product, depending on the degree of development attained by the conditions of production.

MF:655 AMENDED; $\mathrm{M}^{4}: 542$

39 'Neben das Maß der Arbeitszeit als "ausgedehnter Größe" tritt jetzt das Maß ihres Verdichtungsgrads.' Concerning the term 'measure', a general warning - for all of Capital is appropriate: the meaning of the German term ' $m a \beta$ ' is complicated. The relevant meaning here seems near to 'gradation' or 'degree' - or 'measure', as in the phrase 'to considerable measure' (for at least some explication of the term, see Inwood 1992, p. 240).

40 Next to the normal sales of commodities at their value, Marx assumes that the price of labour-power may at times be above its value, but not below it. 
Marx emphasises strongly that the three determinants mentioned in this passage are not only variable, but also may occur separately or in several combinations. In what follows after this passage, he analyses each of these in turn, in four separate sections. Marx here usually assumes that the determinants have been generalised across the economy, whereas the previous chapters that I discussed ( $\$ 3.2$ and $\S 3.3)$ also treated (the initiation of) changes. ${ }^{41}$

\subsection{A Digression on 'Potentiated Labour' in Chapter 1}

By itself, the notion of different value-generating potencies of labour $(\S 3.2)$ is not a novel issue within Marx's systematic of Capital I. In its Chapter 1 he uses a similar notion:

Simple average labour ... varies ... at different cultural epochs ... but in a particular society it is given.... More complex labour counts only as * $p o-$ tentiated $^{*}$ or rather multiplied simple labour, so that a smaller quantity of complex labour *is equal* to a larger quantity of simple labour. (...) In the interests of simplification, we shall henceforth view every *kind* of

41 Marx opens the first section by stating: 'A working day of given length always creates the same amount of value, no matter how the productivity of labour, and, with it, the mass of the product and the price of each single commodity produced may vary.' (MF:656; $\mathrm{M}^{4}: 543$.) Given Marx's earlier exposition ( $\$ 3.2$ above) I take it that he refers to the social averages of labour-time and value. The first section ends with a preview in which Marx moves beyond averages: 'I shall show in *Book III* that the same rate of surplus-value may be expressed in the most diverse rates of profit, and that different rates of surplusvalue may, under certain conditions, be expressed in the same rate of profit.' (MF:66o; $M^{4}: 546-7 ; M^{1}: 423$.) Concerning the last phrase of this sentence: at this point Marx does not seem worried about differing rates of surplus-value. In the second section, he writes: 'Increased intensity of labour means increased expenditure of labour in a given time. (...) Whether the magnitude of the labour changes in extent or in intensity, there is always a corresponding change in the magnitude of the value created, independently of the nature of the article in which that value is *actualised* $\{$ sich darstelt $\}$.' (MF:66o-1, amended; $\mathrm{M}^{4}: 547-8$.) Marx does not posit (here) a tendency toward equalisation of the intensities, but in the following he is perhaps near to suggesting it: 'If the intensity of labour were to increase simultaneously and equally in every branch of industry, then the new and higher degree of intensity would become the normal social degree of intensity, and would therefore cease to count as an extensive magnitude.' (MF:661-2; $M^{4}: 548$.) I suppose that the last 'extensive' is a mistake and that it should instead read 'intensive'. 
labour-power directly as simple labour-power; by this we shall simply be saving ourselves the trouble of making the reduction.

MF:135 AMENDED; ${ }^{42} \mathrm{M}^{4}: 59 ;$ CF. $\mathrm{M}^{1}: 20^{43}$

Note that Marx introduced the intensity of labour six pages earlier on (MF:129) - distinguishing between degree of skill and intensity. The similarity of the Chapter 1 and the Chapter $12^{\text {Ger.10 }}$ notions is that the same clock-time of different kinds of labour creates different quantities of value (due to different labour potencies). The reduction matter in the quotation's last sentence is perhaps acceptable as a simplification in Chapter 1; the problem is rather that Marx never returns to it. ${ }^{44}$

\subsection{Conclusions}

With the composition of capital still being implicit, Parts Three to Five of Capital I are mainly an exposition of the determinants of the average rate of surplus-value, and changes in that rate. The first determinant is the average real-wage rate per working day of labour of average quality. The further determinants are: (1) the length of the working day; (2) the intensity of labour; and (3) the productive power of labour. These further determinants can arise either separately or in several combinations.

The intensity affects the 'density' of labour, while in contrast the productive powers affect its 'potency'. Each of the non-generalised changes in the intensity or the productive power of labour mean that the value produced in one hour of labour diverges between capitals (whether intra-sectoral or inter-sectoral).

Differing intensities of labour can be presumed to be equalised due to competition between workers. However, there is apparently no mechanism for the equalisation of productive powers (or techniques) between sectors. Hence Marx does not posit it: he can only exhibit the matter for single sectors. Given the extra value-generating potencies of labour as associated with

42 Fowkes has 'intensified' for the German 'potenzierte'. In a similar passage in Marx's 1859 Critique, where the German text has 'einfache Arbeit auf höherer Potenz' (Marx 1859, p. 19), Ryazanskaya translates this more appropriately as 'simple labour raised to a higher power' (Marx 1971 [1859], p. 31).

43 There are some deviations between the German editions.

44 In Reuten 1993 it is shown that this reduction precludes the interpretation that Marx would hold any simple pre-market labour-embodied theory of value, because there is no other way to make the reduction than via the labour market. 
above-average productive powers $(\$ 3.2)$, this is a key point, because in this way we obtain diverging rates of surplus-value between sectors, that is, when the development of the productive powers is unequally diffused across the economy.

Addendum. Given Marx's exposition of the productive powers recapitulated above, it is relevant to now briefly refer back to the $1864 / 65$ GRP manuscript. Because, as indicated in $\S 2$, the $1863 / 64 \mathrm{draft}$ for Capital $I$ is missing, we do not know if the conceptualisation from 1867 presented in $\S 3$ is richer than that in the missing manuscript, which is the one that Marx presumably had in mind when he wrote the GRP manuscript.

However, all the evidence that we have points out that Marx developed his insights regarding the technique related 'potency of labour' only in 1866-67 when he worked on the final draft for the first edition of Capital $I$. Regarding the 1861/63 text this can be checked, since we have these texts: $M E C W 30$ and 34 (based on MEGA II/3). Further, of the 1863/64 penultimate draft for "Capital I" we do have the 1864 Results (MECW Volume 34, pp. 355-466). In this text Marx presents a quite extensive treatment of technical change. Nevertheless, as in the earlier manuscripts, he here treats only the intensity of labour.

The term 'productive powers' (or also 'technology') is mentioned several times in Chapters 1-2 of the $1864 / 65$ manuscript (i.e. Parts One to Two of the current Capital III $).{ }^{45}$ However, in those passages Marx keeps the rate of surplus-value constant. ${ }^{46}$ The notion of (extra) value-generating potencies of labour or a variant thereof is not mentioned.

It is appropriate to indicate though that Marx in this $1864 / 65$ manuscript considers specific sectors of production to have developed some specific 'gradation' in the development of the productive powers of labour. Next he associates this gradation with the proportions of the composition of capital:

[T] he specific development of the social productive power of labour in each particular sphere of production varies in degree relative to how large a quantity of means of production is set in motion by a certain quantity of labour ...; such capitals as contain a larger quantity of constant

\footnotetext{
45 Chapter 1 (Part One): MEgA II.4.2, pp. 78-79, 81-2, 103, 108-9, 112, 114-23; Chapter 2 (Part Two): MEGA II.4.2, pp. 241-3, 247.

46 See especially his statement on pages 110, 118 and 164 (Chapter 1/Part One) and 212 (Chapter 2/Part Two).
} 
capital ... than the social average capital are called capitals of higher composition ...47

Finally - keeping the rate of surplus-value uniform - he associates these grades and proportions with the deviations of production prices from values. ${ }^{48}$

\section{An Immanent Reconstruction: The 1864/65 GRP Transformation in Face of Capital I}

\subsection{Introduction}

Although value is produced by labour and labour only, diverging productive powers of labour (and perhaps concomitantly diverging compositions of capital) mean that value and surplus-value cannot be simply explained in terms of labour clock-time.

When we leave the social-averages account, and move to the presentation of sectors of production with their distinct 'gradation' in the development of the productive powers of labour (i.e. the expositional level of 'Capital III, Part Two'), it is far from obvious to posit equalised rates of surplus-value between sectors. Nevertheless, as we have seen $(\S 2)$ this is what Marx does in the GRP manuscript. In that manuscript, he decisively posits the uniformity of rates of surplus-value for all sectors as predicated on the competition between workers. Hence it would seem that (in $1864 / 65$, though not so in 1867 ) rates of surplus-value uniquely reflect the physical intensity aspect of the exploitation of labour, leaving no room for its productive-powers aspect.

Workers, from their own perspective, have an interest in: the real wage (the value of labour-power), the length of the working day and the intensity of labour. These determine the degree of physical exploitation, and these can be supposed to be levelled out by competition among workers. The final determinant of the rate of surplus-value, i.e. the productive powers, is apparently of no importance for their competition (it is the capitalists' thing, so to speak). This

47 He writes this in the text that became Chapter 10 of Capital III: MEgA II/4.2, p. 241, my translation; cf. Fowkes's translation (Marx 2015) p. 276; cf. Das Kapital III, Marx-EngelsWerke Band 25, p. 173; Capital III, Fernbach translation, pp. 263-4). I have amended Fowkes's translation (admittedly from one sentence of about 125 words), the most important point being that he once again has 'productivity' instead of 'productive power'; later he also misplaces the term 'degree'. 
is the key point neglected by Marx in his $1864 / 65$ GRP transformation, whence he posits equalised rates of surplus-value.

As far as I am aware, this position of Marx has never been questioned in the main debates on 'the' transformation problem. ${ }^{49}$

\subsection{Main Elements for a Reconstructive Account of the GRP as a Stage of Concretisation}

The core of a Marx-immanent reconstruction of the GRP problematic is simple.

- First, we posit a tendency to between-sector equalisation of profit rates.

- Second, we posit compositions of capital diverging between sectors.

- Third, we posit diverging rates of surplus-value between sectors, predicated on diverging productive powers and potencies of labour. (Generally, an increase in the rate of surplus-value in a sector concomitant on an increase in the composition of capital is a condition for such a technical change.)

- Fourth, we maintain the Capital I concept of value.

I claim that there is no friction between these four theses. We thus have no GRP transformation problematic, and much of what is written in Part Two of Capital III is redundant, including the concept of prices of production. Because of the maintenance of the Capital I concept of value, any valuetheoretical duality between Capital I and Capital III is eliminated. Therefore, output transformation or input transformation is also redundant. In brief, we have continuity of the concept of value for each of Capital's expositional levels.

Generally speaking, the systematic insufficiency, or incompleteness, of Marx's 1864/65 draft for Capital III is that he moves to a consideration of sectoral differences without having concretised his 'Capital I' account of social average production into sectors of production. Thus he skips a step, and is so bound to phrase the matter immediately (i.e. non-mediated) in terms of market-supply phenomena (which, I might add, for a major conceptual transformation, seems not quite fitting for the marxian paradigm).

49 However, prior to those main debates (prior to the publication of Capital III) two authors, George Stiebeling (Stiebeling 1890) and Julius Wolf (Wolf 1891), anticipated in fairly general terms the relevance of the productive powers for divergent sectoral rates of surplus-value. They expressed their views in connection with Engels's (1885) 'prize essay contest' about the consistency of 'the law of value' in face of divergent sectoral compositions of capital. (These texts are discussed in Reuten 2018, Appendix.) Their contributions were inaptly ridiculed by Engels in his Preface to Capital III. 
Hence the reconstructed conceptual progress, or concretisation, of Capital III, Part Two, that I propose, concerns, first, the explicit introduction of a general (i.e. average) rate of profit, and second, abandoning the Capital I production averages, so that we have differentiated sectors of production. That is also Marx's aim.

In particular, this reconstructed concretisation moves from the explanation of the social average surplus-value produced (Capital I) to the explanation of the sectors' production of surplus-value. In a way, this is formally in line with Marx, be it that in the $1864 / 65$ manuscript he implicitly posits that this matter requires no concretisation: rates of surplus-value tend to equalise between sectors.

The concretisation also includes the explicit introduction of the composition of capital (c/v) - which was mostly only implicit in Part Four of Capital I (see §3.1 point 4).

The Appendix below sets out this reconstruction in more detail, making use of some simple formalisations. It treats especially increasing productive powers in one sector in comparison with the economy as a whole, along with the three cases of constant, increasing and decreasing compositions of capital.

To understand the context of this reconstruction correctly, I should make the following explicit. More so than Marx in the current context, I put emphasis on the point that the social development of the productive powers of labour - that is, technology as well as its potential application in techniques is the product of labour and labour only..$^{50}$ However, capital appropriates these and the management of capital decides which particular techniques are actually applied and specifically developed (by labour) for specific production processes. Thus, in as much as labour produces capital - via the production of surplus-value and capital's appropriation of it - it produces the potential technical forms of the production processes and hence labour's productive power. In brief, in capitalism the development of the productive powers of labour takes the value-form.

\subsection{Implications of the Reconstruction}

The reconstruction strengthens Marx's explanation of surplus-value. The central idea is the diverging value-generating potencies of labour between sectors,

50 I make a distinction, as Marx does, between 'technology' (knowledge about and search for potential techniques) and 'technique' (the particular application of technology in production). It is akin to Schumpeter's and Christopher Freeman's distinction between 'invention' and 'innovation' (see Reuten and Williams 1989, pp. 80 and 119-21). 
associated with diverging states of the productive powers between sectors. There are five implications:

1. Contrary to the $1864 / 65$ G RP manuscript for Capital III, we have no transformation of value concepts, no dual account systems, and no artificial value and surplus-value adjusting transfers that would question the status of the Capital I determinations.

2. The reconstruction maintains the monetary value account - established in Capital I - throughout the terrains of each of the levels of the three volumes of Capital, as including the exposition of all specific and concrete market phenomena in terms of balanced or imbalanced market prices. Again, it merely excludes prices of production and hence the implied account duality.

3. The reconstruction does not affect the determination of average surplusvalue by the average exploitation of labour as set out in Capital $I$.

4. Given the real wage, the length of the working day (or year) and the intensity of labour, the production of surplus-value in each one sector is determined by the value-generating potencies of labour. Sectoral divergences of the latter are predicated on the degree of diffusion of the productive powers of labour. In other words, these are predicated on the degree of diffusion of technology into techniques applied in each sector - technology and techniques themselves being the product of social labour.

5. The 'productive powers' component of surplus-value and the rate of surplus-value has explanatory power. However (and as far as I can see now) it can be measured only indirectly (this is a defect, even if it also applies to many accepted theories in the social and natural sciences).

\section{Summary and Conclusions}

I revisited what probably is the main problem with Marx's Capital, namely the concretising transformation of the Capital I value concepts into the prices of production of Capital III, Part Two - dubbed the 'transformation problem'. As a quantitative transformation, it posits dual account systems.

In what became Part Two of Capital III, and in the 1864/65 research manuscript for it, Marx set out a number of constraining incompatible presuppositions for that transformation. Key presuppositions are the sale of commodities 'at their values' and equalised rates of surplus-value. To get rid of the incompatibility of presuppositions, Marx then abandons the first one, although he is hesitant to do so, because of its severe implications for his (draft stage) 'Capital I' exposition $(\S 2)$. 
In the more than 120-year history of the appraisal of that transformation, the main focus has been on the analytical shortcomings of that transformation (shortcomings which I do not question, given the way it was posited). That appraisal leaves the constraints as finally posited by Marx untouched. In this article, I have set out a Marx-immanent critique of his positing of these constraints, and especially the presupposition of equalised rates of surplus-value.

To achieve this, I scrutinised Marx's exposition of surplus-value and the rate of surplus-value in Capital I - especially Parts Four and Five - an exposition which I accept. In brief, given a real wage, the rate of surplus-value is determined by (1) the length of the working day; (2) the intensity of labour; and (3) the productive power of labour. Changes in each of these three can arise either separately or in various combinations. In these Parts, Marx presents these in terms of social averages and their changes $\left(\$_{3}\right)$.

Key to the defect of Marx's 1864/65 transformation is its disregard of the development of the productive powers of labour that is presented in the 1866/67 thoroughly-reworked version of Capital $\mathrm{I}$. In the latter we find that while there are mechanisms for the equalisation of wages between sectors, the working day and the intensity of labour, there is no mechanism for the equalisation of the productive powers between sectors. Marx justifiably does not posit the latter (\$3.2). In particular, he does not posit an equalisation of the composition of capitals. Confronted by the transformation problem, the heart of the matter turns out to be that Marx's Capital $I$ associates diverging productive powers of labour with diverging value-generating potencies of labour (\$3.2).

In the reconstruction which I set out in $\S 4$ (and in more detail in the Appendix), I carry over these Capital I notions to the level of concretisation in 'Capital III'. Marx's transformation (and its problem) is then transcended into a concretisation of the averages account of Capital $I$, especially with regard to divergences between sectors in their productive powers, and the concomitant value-generating potencies of labour. Because of these divergences, we have divergent rates of surplus-value. This concretisation is consistent with diverging composition of capitals and equalising or equalised rates of profit. Thus, the transformation of the Capital I concept of value into 'prices of production' becomes redundant. The result is a continuity of the concept of value for each of Capital's levels of exposition.

With Capital $I$ in retrospect, and equipped with the reconstruction, we can see that Marx's 1864/65 GRP constraints posit the matter in a static way: we have divergent sectoral compositions of capital. However, dynamically considered, we have diverging compositions of capital because diverging rates of surplus-value are their condition. 


\section{Appendix (to §4). Core Analytics of an Immanent Reconstruction of the GRP Transformation in Face of Capital I}

\section{Preliminary Remarks}

In $\S 4$ I proposed a reconstruction of Part Two of Capital III in face of Part Four of Capital I. In this Appendix I set out a simple formalisation of the analysis that underlies this reconstruction. It builds on the between-sectors diverging rates of surplus-value that Marx introduced in Capital $I$ at a point when he digressed from his averages account of that book (cf. §3). It is appropriate to build on that because the GRP transformation is pre-eminently about between-sector differences.

Recall the four main elements of the reconstruction summed up at the beginning of $\$ 4.2$. Given a tendency to equalisation of rates of profit, I focus on two variables in terms of Capital I's monetary-value dimension. First, the rate of surplus-value and its divergence between sectors as determined by the productive powers. Given Marx's mature exposition of these (1867), it is far from obvious to posit equalised rates of surplus-value between sectors as he did in an earlier research manuscript (1864/65). Second, the organic composition of capital (c/v), which was mostly only implicit in Part Four of Capital I (see §3.1 point 5).

With regard to details of the reconstruction, I will add a terminological point. Just as Marx did at the start of his GRP manuscript, I treat surplus-value as being identical to profit. My reason is that the distribution of surplus-value to financiers has not yet been introduced. However, because the reconstruction makes 'prices of production' redundant, surplus-value keeps on being identical to profit prior to the explicit introduction of finance.

\section{Analytics of Technical Change along with Increasing Productive Powers, and Associated with Varying Organic Compositions of Capital}

I set out a brief point-wise presentation of the main elements of the reconstruction. Generally, there are three possibilities regarding the combination of increasing productive powers of labour (PPL) and of the organic composition of capital (CC): first, a constant CC; second, an increasing CC; third, a decreasing CC. I consider each of these in turn.

1 The productive powers in a sector increase along with a constant cc

If the PPL rise while the $\mathrm{CC}$ is constant, the change is without costs. I suppose that this is what Marx generally had in mind in Capital I, Parts Four and Five. In this case, we have - after competitive adaptation - a pure decrease in the value 
of commodities and so an increase in relative surplus-value (that is, to the extent that the commodity at hand makes part of the wage bundle).

- Upon introduction of the new technique, the initiator makes an extra surplus-value due the increased value-generating potencies of labour, that is, at a constant market price. Along with it, the initiator's rate of profit rises above the average.

$$
\mathbf{P P L} \uparrow, \mathrm{CC} \text { constant } \rightarrow \mathrm{s}_{\mathrm{I}}^{\prime} \uparrow \text { and } \mathbf{r}_{\mathrm{I}}^{\prime}>\mathbf{r}_{\mathrm{S}}^{\prime}=\mathbf{r}_{\mathrm{E}}^{\prime}
$$

(From here on I use the following notation: $s$ = surplus-value; $\mathrm{s}^{\prime}=$ rate of surplus-value; $\mathrm{r}^{\prime}$ = rate of profit; subscripts: $\mathrm{I}$ = initiator; $\mathrm{S}=$ sector; $\mathrm{E}=$ economy.)

- Competitors follow suit, and because of the above-average rate of profit there will also be an extra investment (by the initiator, competitors or entrants) which forces the market price downward. ${ }^{51}$ This price decrease devalues the initial extra value-generating potency of labour. I call this a 'devaluation', because an increased value-generating potency results in fact in a revaluation.

competition $\rightarrow \mathbf{p} \downarrow \rightarrow \mathbf{s}_{\mathrm{I}}^{\prime}=\mathbf{s}_{\mathrm{S}}^{\prime}=\mathbf{s}_{\mathrm{E}}^{\prime}($ result of devaluation $)$ and $\mathbf{r}_{\mathrm{I}}^{\prime}=\mathbf{r}_{\mathrm{S}}^{\prime}=\mathbf{r}_{\mathrm{E}}^{\prime}$

- The result is a normal, and ultimately generalised, increase in relative surplus-value; that is, to the extent that the commodity at hand makes, directly or indirectly, part of the wage bundle.

51 I draw a distinction between production-process competition and market competition. Only additional supply of the commodity at hand (predicated on extra investment) will ceteris paribus lower the market price. The above-average rate of profit (predicated on the production-process competition) induces this extra investment, and hence this market competition. In case the new technique requires an increase in scale, we would have already upon its initiation an extra investment and an additional supply, and some downward pressure on the market price. This qualification also applies for the next two cases. (I disregard any market-strategic-pricing considerations, which would belong at a more concrete level of the exposition.). 
$\mathbf{p} \downarrow($ relative surplus-value $\uparrow) \rightarrow$ generalised $\mathbf{s}^{\prime} \uparrow$ and $\mathbf{r}^{\prime} \uparrow$

This part of the concretisation is directly in line with Marx's Capital I, Part Five (moreover, there is no problem of different ccs).

\section{The productive powers in a sector increase along with the cc increasing}

In the second case the PPL increase in a sector along with a rise in CC. A capitalist introduces a CC-raising technique only if this raises the rate of surplusvalue such that the rate of profit rises as a result (or remains at least constant). Thus, the expectation of a rise in the rate of surplus-value is a condition for a rising cc. This is a very simple point, but a key one for the whole discussion. ${ }^{52}$

2-a. For analytical reasons, I start by considering the period before any competitor has adopted the new technique; along with it I assume constant market prices. ${ }^{53}$

- Upon the introduction of the CC-raising technique (as predicated on increasing PPL), the initiator obtains an extra surplus-value due to the increased potencies of labour (this is in line with Marx 1867). ${ }^{44}$ Along with it, the initiator's rate of profit moves above the average.

$\mathbf{P P L} \uparrow, \mathbf{C C} \uparrow \rightarrow \mathbf{s}_{\mathrm{I}}^{\prime} \uparrow$ and $\mathbf{r}_{\mathrm{I}}^{\prime}>\mathbf{r}_{\mathrm{S}}^{\prime}=\mathbf{r}_{\mathrm{E}}^{\prime}$

- Because of constant market prices, the increase in PPL has no effect on the relative surplus-value. In fact, the absolute surplus-value increases without

$5^{2}$ Within any other theoretical constellation - (including the ones that I contest) and in whatever way profits are explained - an expected rise in profits such that the rate of profit remains at least constant is also a condition.

53 In order to keep the presentation concise, I will disregard, for this and the next point, any market-strategic considerations for gaining an increased market share. These are relevant for a further concretisation, although they do not inherently pertain to changes in productive powers, because 'market share competition' - e.g. a (temporary) price-decreasing one - might occur independently of it.

54 Thus the aggregate surplus-value increases. This is not different for Marx's presentation in Capital I, Chapter $12^{\text {Ger.10 }}$ ( $\$ 3.2$ above). 
an increase in the length of the working day. ${ }^{55}$ I call this 'compressed absolute surplus-value'.

2-b. We now drop the assumption of a constant market price, and consider effective production-process competition. Again, for the initiator we have:

$\mathbf{P P L} \uparrow, \mathbf{C C} \uparrow \rightarrow \mathbf{s}_{\mathrm{I}}^{\prime} \uparrow$ and $\mathbf{r}_{\mathrm{I}}^{\prime}>\mathbf{r}_{\mathrm{S}}^{\prime}=\mathbf{r}_{\mathrm{E}}^{\prime}$

$(5)=(4)$

- Now competitors follow suit, and extra investment (by the initiator, competitors or entrants) forces the market price down, thereby devaluing some of the initial extra value-generating potency of labour.

- Extra investment (and price decrease) continues up to the point where the sector rate of profit $\left(\mathrm{r}_{\mathrm{S}}\right)$ is averaged out. ${ }^{56}$ Given the increase in CC, this averaging-out of the sector's rate of profit will be reached at a point where the sector rate of surplus-value is higher than the economy average rate $\left(\mathrm{s}_{\mathrm{S}}>\mathrm{s}_{\mathrm{E}} \mathrm{E}\right)$; hence, the value-potency of labour is devalued up to that point. Thus the extra value-potency of labour (and hence the increased sector rate of surplus-value) will not completely vanish, since there is no capitalist motive or force or mechanism for any further price decrease that would push the rate of profit below the average.

competition $\rightarrow \mathbf{p} \downarrow \rightarrow \mathbf{s}_{\mathrm{I}}^{\prime}=\mathrm{s}_{\mathrm{S}}^{\prime}>\mathrm{s}_{\mathrm{E}}^{\prime}$ (result of partial devaluation) and $\mathbf{r}_{I}^{\prime}=\mathbf{r}_{S}^{\prime}=\mathbf{r}_{E}^{\prime}$

- The result is a combination of, first, an increase in the 'compressed absolute surplus-value' for this sector (due to the lasting increase in labour potency for this sector) and, second, an economy-wide increase in relative surplusvalue (to the extent that the price decrease affects the wage bundle).

55 The qualification about this type of absolute surplus-value was pointed out by Chris Arthur in the conference discussion, based on an earlier version of this paper.

56 All these are notions of pure theory (in an equilibrium framework the final match will be exact). In practice all such investments are more-or-less rough guesses or expectations. 
- sector effect:

$\mathbf{p} \downarrow \rightarrow \mathbf{s}_{\mathrm{I}}^{\prime}=\mathbf{s}_{\mathrm{S}}^{\prime}>\mathbf{s}_{\mathrm{E}}^{\prime}$ (partial devaluation) and $\mathbf{r}_{\mathrm{I}}^{\prime}=\mathbf{r}_{\mathrm{S}}^{\prime}=\mathbf{r}_{\mathrm{E}}^{\prime}$

- economy-wide effect (as including on the sector at hand):

$\mathbf{p} \downarrow($ restricted relative $\mathbf{s} \uparrow) \rightarrow$ generalised $\mathbf{s}^{\prime} \uparrow$ and $\mathbf{r}^{\prime} \uparrow\left(\right.$ at $\left.\mathbf{r}_{\mathrm{I}}^{\prime}=\mathbf{r}_{\mathrm{S}}^{\prime}=\mathbf{r}_{\mathrm{E}}^{\prime}\right)$

Recall from $\$ 3.2$ that such changes and divergences in the rate of surplus-value between sectors are in line with Marx's 1867 Part Four exposition. However, at that point in the 1867 exposition, he has the CC and the rate of profit implicit; we now have made these explicit, so concretising the exposition at a 'Capital III' level. Marx probably assumed that the 'compressed absolute surplus-value', i.e. the increased potency of labour, would vanish (see the third citation in $\$ 3.2$ ), because he implicitly held the CC unchanged. In that case, we have the constellation set out under point 1 above.

\section{The productive powers in a sector increase along with the cc decreasing}

The case of an increase in PPL along with a decrease in the CC has effects similar to case 1 (although now CCs diverge across the economy).

- The initiator's introduction of a new technique:

$$
\mathbf{P P L} \uparrow, \mathbf{C C} \downarrow \rightarrow \mathbf{s}_{\mathrm{I}}^{\prime} \uparrow \text { and } \mathbf{r}_{\mathrm{I}}^{\prime}>\mathbf{r}_{\mathrm{S}}^{\prime}=\mathbf{r}_{\mathrm{E}}^{\prime}
$$

- Competition and extra investment:

$$
\begin{aligned}
& \text { competition } \rightarrow \mathbf{p} \downarrow \rightarrow \mathbf{s}_{\mathrm{I}}^{\prime}=\mathbf{s}_{\mathrm{S}}^{\prime}<\mathbf{s}_{\mathrm{E}}^{\prime}(\text { result of devaluation) and } \\
& \mathbf{r}_{\mathrm{I}}^{\prime}=\mathbf{r}_{\mathrm{S}}^{\prime}=\mathbf{r}_{\mathrm{E}}^{\prime}
\end{aligned}
$$

Now the equalisation of the rate of profit is reached at a sector rate of surplusvalue below the average one $\left(s_{S}^{\prime}<s_{E}^{\prime}\right)$.

- To the extent that the lower sector price affects the wage bundle, we have a generalised increase in relative surplus-value, and hence a generalised increase in the rate of profit.

$$
\mathbf{p} \downarrow(\text { relative surplus-value } \uparrow) \rightarrow \text { generalised } \mathbf{s}^{\prime} \uparrow \text { and } \mathbf{r} \uparrow
$$


See $\S 4.3$ of the main text for the conclusions.

Addendum on the status of a transformation. In line with what Marx wrote about this, Part One of 'Capital III' can be characterised as a conceptual transformation. ${ }^{57}$ Concomitant on making the driving force of 'the rate of profit' explicit, this transformation concerns mainly the transformation of the concept of surplus-value into profit - each one value concepts.

Part Two in fact makes it explicit that the driving force of the rate of profit entails that capitals move from low- to high-rate-of-profit sectors, so establishing a tendency to equalisation of rates of profit (the 'general rate of profit'). It is somewhat arbitrary whether in the reconstruction presented above, this should still be called a transformation. We have no new transformation of an earlier value concept (as in Part One). If anything, we have transformations of the physical guise of capital (producing e.g. soap instead of sweets). ${ }^{58}$

\section{References}

Backhaus, Hans-Georg 1969, 'Zur Dialektik der Wertform', in Beitrage zur Marxistischen Erkenntnistheorie, edited by Alfred Schmidt, Frankfurt: Suhrkamp. Translated by M. Eldred and M. Roth, 'On the Dialectics of the Value-form', Thesis Eleven, 1, 1980, pp. 90-120.

Bellofiore, Riccardo 2005, 'The Monetary Aspects of the Capitalist Process in Marx: A Re-reading from the Point of View of the Theory of the Monetary Circuit', in Marx's Theory of Money: Modern Appraisals, edited by Fred Moseley, Basingstoke: Palgrave-Macmillan.

Campbell, Martha 1997, 'Marx's Theory of Money: A Defense', in New Investigations of Marx's Method, edited by Fred Moseley and Martha Campbell, Albany, NJ: Humanities Press.

57 Chapter 1: 'Materially $\{$ Stoff; stofflich $\}$ considered ... the profit ... is not different from the surplus-value itself. Hence its absolute magnitude is not different from the magnitude of the surplus-value (...) it is however a transformation \{verwandelte Form $\}$ of the latter ...' (M:8-9-mt; cf. MF:50) $\leftrightarrow($ Marx 1993 and Marx 2015). Engels omits this text in Capital III.

$5^{8}$ I have no objection in principle to calling this a (particular) transformation. In reference to a comment by one of the reviewers for Historical Materialism I add that I would even have no objection to calling the resulting constellation one of 'prices of production', were it not that the history of marxian political economy has been such that this name now stands for quite some more: value adjustments and dual systems. 
Elson, Diane 1979, 'The Value Theory of Labour', in Value: The Representation of Labour in Capitalism, edited by Diane Elson, London: cSE Books.

Engels, Friedrich 1885, 'Vorwort' to Das Kapital II (see MEgA II/13); 'Preface' to Capital II (see Marx 1978).

Engels, Friedrich 1894, 'Vorwort' to Das Kapital III (see Marx 1964); 'Preface' to Capital III (see Marx 1981).

Howard, Michael Charles and John Edward King 1989, A History of Marxian Economics: Volume I, 1883-1929, London: Macmillan.

Inwood, Michael 1992, A Hegel Dictionary, Oxford: Blackwell.

Kopf, Eike, Willi Bang, Joachim Conrad and Edgar Klapperstück 1983, 'Einleitung zu MEGA II $/ 5$ ' (see MEGA II/5, pp. $1^{*}-55^{*}$ ).

Marx, Karl 1859, Zur Kritik der politischen Ökonomie, MEGA II/2; Marx-Engels-Werke Band 13, available at: <https://marxwirklichstudieren.files.wordpress.com/2012/11/ mew_bandi3.pdf $>$.

Marx, Karl 1867¹, Das Kapital. Kritik der politischen Oekonomie. Buch I: Der Produktionsprocess des Kapitals [first edition], Hamburg: Verlag von Otto Meissner (see MEGA II/5).

Marx, Karl 1962 [18904], Das Kapital, Kritik der Politischen Ökonomie; Erster Band, Der Produktionsproze $\beta$ des Kapitals, fourth edition, edited by Friedrich Engels, in MarxEngels-Werke Band 23, Berlin: Dietz Verlag.

Marx, Karl 1964 [1894], Das Kapital, Kritik der Politischen Ökonomie; Dritter Band, Der Gesamtprozeß der kapitalistischen Produktion, edited by Friedrich Engels, in MarxEngels-Werke Band 25, Berlin: Dietz Verlag.

Marx, Karl 1971 [1859], A Contribution to the Critique of Political Economy, edited by Maurice Dobb and translated by S.W. Ryazanskaya, London: Lawrence \& Wishart.

Marx, Karl 1976 [1890 ${ }^{4}$, Capital: A Critique of Political Economy. Volume One, translated by Ben Fowkes from the fourth German edition (see Marx 1962), Harmondsworth: Penguin.

Marx, Karl 1978 [1885], Capital: A Critique of Political Economy. Volume Two, translated by David Fernbach from the German edition, Harmondsworth: Penguin.

Marx, Karl 1981 [1894], Capital: A Critique of Political Economy. Volume Three, translated by David Fernbach from the German edition (see Marx 1964), Harmondsworth: Penguin.

Marx, Karl 1993, research manuscript for Capital III of 1864-5, MEGA II/4.2.

Marx, Karl 2010 [1887], Capital: A Critical Analysis of Capitalist Production. Volume I, edited by Frederick Engels, translated by Samuel Moore and Edward Aveling, MECW 35 (digital edition), London: Lawrence \& Wishart.

Marx, Karl 2015, research manuscript for Capital III of 1864-5 (see Marx 1993), translated from MEGA II/4.2 by Ben Fowkes, Marx's Economic Manuscript of 1864-1865, 
edited and with an introduction by Fred Moseley, Historical Materialism Book Series, Leiden: Brill.

ME GA II /2, ${ }^{59}$ Ökonomische Manuskripte und Schriften 1858-1861 (einschl. Zur Kritik der politischen Ökonomie, 1859), Berlin: Dietz Verlag 1980.

MEGA II/4.2, Ökonomische Manuskripte 1863-1867, Teil 2: Manuskript 1863/65 zum

3. Buch des „Kapital”, arranged and edited by Manfred Müller, Jürgen Jungnickel,

Barbara Lietz, Christel Sander and Arthur Schnickmann, Berlin: Dietz Verlag 1993. MEGA II/4.3, Ökonomische Manuskripte 1863-1867, Teil 3: Manuskripte 1867-68 zum 2. und 3. Buch des „Kapital”, arranged and edited by Carl-Erich Vollgraf with Larisa Mis'kevic, Berlin: Akademie Verlag 2012.

MEgA II/5, Das Kapital. Kritik der Politischen Ökonomie. Erster Band, Hamburg 1867, Berlin: Dietz Verlag 1983, available at: <http://telota.bbaw.de/mega/>.

MEGA II/13, Das Kapital. Kritik der politischen Ökonomie. Zweiter Band. Herausgegeben von Friedrich Engels. Hamburg: Verlag von Otto Meissner 1885, arranged and edited by Izumi Omura, Keizo Hayasaka, Rolf Hecker, Sejiro Kubo, Akira Miyakawa, Kenji Mori, Sadao Ohno, Regina Roth, Shinya Shibata and Ryojiro Yatuyanagi, Berlin: Akademie Verlag 2008, available at: <http://telota.bbaw.de/mega/ $>$.

MEGA II/14, Manuskripte und redaktionelle Texte zum dritten Buch des „Kapitals”, 1871 bis 1895, arranged and edited by Carl-Erich Vollgraf and Regina Roth, with Jürgen Jungnickel, Berlin: Akademie Verlag 2003.

MEGA II/15, Das Kapital. Kritik der politischen Ökonomie. Dritter Band, Herausgegeben von Friedrich Engels. Hamburg 1894, arranged and edited by Regina Roth, Eike Kopf and Carl-Erich Vollgraf, with Gerald Hubmann, Berlin: Akademie Verlag 2004, available at: <http://telota.bbaw.de/mega/ >.

Moseley, Fred 2015, Money and Totality: A Macro-Monetary Interpretation of Marx's Logic in Capital and the End of the 'Transformation Problem', Historical Materialism Book Series, Leiden: Brill.

Moseley, Fred and Tony Smith (eds.) 2014, Marx's Capital and Hegel's Logic, Historical Materialism Book Series, Leiden: Brill.

Reuten, Geert 1988, 'Value as Social Form', in Value, Social Form and the State, edited by Michael Williams, London: Macmillan, available at: <http://reuten.eu>.

Reuten, Geert 1993, 'The Difficult Labour of a Theory of Social Value: Metaphors and Systematic Dialectics at the Beginning of Marx's Capital', in Marx's Method in Capital: A Re-examination, edited by Fred Moseley, Albany, NJ.: Humanities Press, available at: $<$ http://reuten.eu $>$.

Reuten, Geert 2004, 'Productive Power and the Degree of Intensity of Labour: Marx's Concepts and Formalizations in the Middle Part of Capital $I$, in The Constitution

59 For the complete list of works of MEGA II, see <http://mega.bbaw.de/struktur/abteilung_ii $>$. 
of Capital: Essays on Volume I of Marx's 'Capital', edited by Riccardo Bellofiore and Nicola Taylor, Basingstoke: Palgrave-Macmillan, available at: $<$ http://reuten.eu >.

Reuten, Geert 2009, 'Marx's Rate of Profit Transformation: Methodological, Theoretical and Philological Obstacles', in Re-reading Marx - New Perspectives after the Critical Edition, edited by Riccardo Bellofiore and Roberto Fineschi, Basingstoke: PalgraveMacmillan, available at: $<$ http://reuten.eu $>$.

Reuten, Geert 2018, forthcoming, 'The Redundant Transformation to Prices of Production: A Marx-immanent Critique and Reconstruction', in Marx's Capital - An Unfinished and Unfinishable Project?, edited by Gerald Hubmann and Marcel van der Linden, Historical Materialism Book Series, Leiden: Brill.

Reuten, Geert and Michael Williams 1989, Value-Form and the State: The Tendencies of Accumulation and the Determination of Economic Policy in Capitalist Society, London: Routledge.

Schefold, Bertram 2004, 'Einführung zu MEGA II/15', in Das Kapital, Kritik der politischen Ökonomie, Dritter Band, MEGA II/15, pp. 871-910.

Stiebeling, George C. 1890, Das Werthgesetz und die Profit-Rate; Leichtfaßliche Auseinandersetzung einiger wissenschaftlicher Fragen; Mit einem polemischen Vorwort, New York: Heinrich, available at: <http://library.fes.de/pdf-files/bibliothek/ bestand/a79-03605.pdf $>$.

Vollgraf, Carl-Erich 2012, 'Einführung zu MEGA II/4.3', in MEGA II/4.3, pp. 421-74.

Vollgraf, Carl-Erich 2018, forthcoming, 'Marx's Further Work on Capital after Publishing Volume 1: On the Completion of Section II of the MEGA', in Marx's Capital - An Unfinished and Unfinishable Project?, edited by Gerald Hubmann and Marcel van der Linden, Historical Materialism Book Series, Leiden: Brill.

Williams, Michael 2000, 'Why Marx neither Has nor Needs a Commodity Theory of Money', Review of Political Economy, 12, 4: 435-51.

Wolf, Julius 1891, 'Das Rätsel der Durchschnittsprofitrate bei Marx', Jahrbücher für Nationalökonomie und Statistik, III. Folge 57, Band II, pp. $35^{2-367}$, available at: <http://www.digizeitschriften.de/download/PPN345616359_0057/log76.pdf>. 